\title{
Estimation of clearness index from different meteorological parameters in IRAQ
}

\author{
Dr. Waleed I . AL-Rijabo, Zahraa M.H \\ College of education, dept . of physics, Mosul University
}

\begin{abstract}
The aim of this paper is to estimate the mean monthly values of clearness index in five meteorological stations in Iraq (Mosul, Kirkuk, Rutba , Baghdad, Nasiriya) for the period (1970-2000) using different meteorological parameters. Five different models (Linear, Quadratic, Logarithmic, Linear logarithmic, Power) were used to estimate clearness index. The performance of this regression models were evaluated by comparing the calculated clearness index and the measured clearness index. Several statistical tests were used to control the validation and goodness of the regression models in terms of correlation coefficient, coefficient of determination, Mean absolute error and root mean square error. Results showed that Linear model between $(K T \& n / N)$ and between $(K T \&$ Rainfall) were the best fit in all stations. Quadratic model were the best fit between ( $K T \&$ \& cloudiness), and power model were the best fit between (KT \&Evaporation). Linear model and Quadratic model were the best fit between (KT \& RH), while power model, Quadratic model, and Linear model were the best fit between (KT \& Tmean).
\end{abstract}

\section{Introduction}

Clearness index is define as the ratio between the global solar radiation at ground level on horizontal surface and the corresponding extraterrestrial radiation ${ }^{(1)}$. The monthly mean clearness index $\mathrm{KT}=\mathrm{H} / \mathrm{Ho}$ Where $\mathrm{H}$ is the monthly mean global solar radiation on horizontal surface Ho is the monthly mean extraterrestrial radiation. clearness index is a parameters of real importance in designing of a renewable energy sources system ; it can provide information concerning the read solar radiation compared with the variable solar radiation ${ }^{(2,3)}$. Clearness index can describes the attenuation of solar radiation due to clouds and aerosols and it depends on the geographical coordinates of the location for watch calculated ${ }^{(4,5)}$.

Several methods have been Proposed for prediction of clearness index ${ }^{(6,7,8)}$. Almost all these models make use of a few meteorological data such as hours of bright sunshine cloudiness, relative humidity, wind speed, altitude precipitation and ambient temperature ${ }^{(9,10,11)}$.

Iraq in located between $29.5^{\circ} \mathrm{N}$ and $37.22^{\circ} \mathrm{N}$ latitude and most of its cites enjoy favorable sunshine whole year around.

In this paper correlations are proposed for monthly mean clearness index (KT) for (Mosul, Kirkuk, Rutba , Baghdad, Nasiriya) stations based on meteorological data for the period (2000-1970) Then calculated KT are compared with measured values.

\section{Materials and Methods}

Mean monthly values of total solar radiation, relative humidity air temperature, cloudiness, rainfall, evaporation are obtained from Iraqi meteorological organization .

The data obtained covered a period of 31 year (1970-2000)for five stations in Iraq listed in table (1) and displayed in Fig. (1).

The mean monthly values of extraterrestrial radiation $(\mathrm{Ho})$ is calculated from the following equation :

$\Phi$ : is the latitude of the location, Eo is the eccentricity correlation factor, $\delta$ is the declination,Ws is the hour angle corresponding to sun-shine or set and Isc is the solar constant having a value of $1367 \mathrm{w} / \mathrm{m}^{2}$.

The expressions of Eo,$\delta$ and Ws are given by Iqbal ${ }^{(5)}$.

dn is the day number of the year .

Mean monthly values of clearness index were computed for the different stations during the period (1970-2000). A number of regression models (Linear, Quadratic, Logarithmic, Linear logarithmic, Power) were investigated and validated to estimate the mean monthly clearness index using different meteorological parameters in the five stations.

In order to select the best model ,mean absolute error (MAE), root mean square error (RMSE), coefficient of determination $\left(\mathrm{R}^{2}\right)$, correlation coefficient $(\mathrm{R})$ were used as the main criteria .The goodness of fit was judged by the size of coefficient of determination, MAE, RMSE and were computed as further check on the stability of the models.

Table(1) : Geographical coordinate of the stations 
Estimation of clearness index from different meteorological parameters in IRAQ

\begin{tabular}{|c|c|c|c|}
\hline Stations & Latitude & Longitude & (Altitude(m \\
\hline Mosul & $36^{\circ} 19^{\prime}$ & $43^{\circ}$ '09 & 223 \\
\hline Kirkuk & $35^{\circ} 28^{\prime}$ & $44^{\circ} \prime 25$ & 331 \\
\hline Baghdad & $33^{\circ} 18^{\prime}$ & $44^{\circ} \prime 24$ & 32 \\
\hline Rutba & $33^{\circ} 02^{\prime}$ & $40^{\circ}{ }^{\prime} 17$ & 630 \\
\hline Nasiriya & $31^{\circ} 05^{\prime}$ & $46^{\circ}{ }^{\prime} 14$ & 5 \\
\hline
\end{tabular}

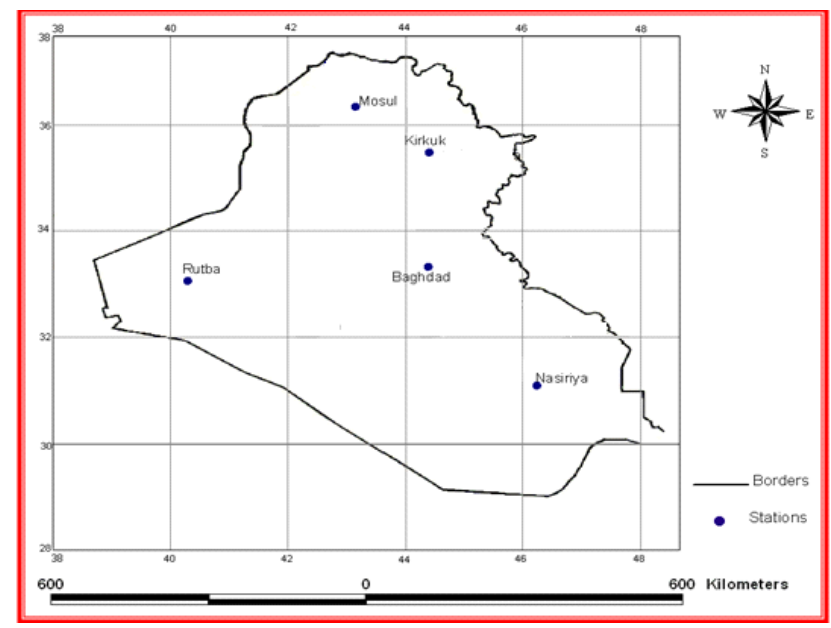

Fig (1) : Location of the five meteorological stations in Iraq's

Table $(2,3,4,5,6)$ show the mean monthly meteorological parameters in all stations during the period (19702000).

Table (2):Mean Monthly meteorological parameters for Mosul station during the period (1970-2000)

\begin{tabular}{|c|c|c|c|c|c|c|c|c|c|c|c|c|}
\hline $\begin{array}{l}\text { Months } \\
\text { Meteo. ele. }\end{array}$ & JAN & FEB & $\begin{array}{c}\text { MA } \\
\text { R }\end{array}$ & APR & MAY & JUN & JUL & AUG & SEP & OCT & NOV & DEC \\
\hline $\mathrm{n} / \mathrm{N}$ & 0.49 & 0.56 & 0.57 & 0.62 & 0.73 & 0.83 & 0.86 & 0.88 & 0.86 & 0.76 & 0.64 & 0.48 \\
\hline Mean air temp. $\left(\mathrm{c}^{\mathrm{o}}\right)$ & 7.0 & 8.8 & 12.6 & 18.0 & 24.5 & 30.4 & 34.1 & 33.1 & 28.4 & 21.4 & 13.8 & 8.5 \\
\hline RH\% & 80.2 & 73.5 & 67.6 & 60.2 & 42.9 & 27.3 & 24.1 & 25.7 & 30.6 & 45.7 & 65.5 & 79.9 \\
\hline total cloud (octa) & 4.3 & 4.2 & 4.1 & 3.9 & 2.9 & 1.1 & 0.4 & 0.3 & 0.7 & 2.3 & 3.1 & 4.7 \\
\hline Evaporation(mm) & 32.5 & 51.8 & 96.4 & 145.4 & 247.6 & 349.8 & 412.3 & 373.6 & 257.1 & 151.5 & 68.4 & 31.4 \\
\hline Rainfall(mm) & 63.2 & 62.1 & 67.8 & 43.2 & 17.0 & 1.2 & 0.2 & 0.0 & 0.3 & 11.4 & 45.1 & 60.4 \\
\hline $\mathrm{H} \quad\left(\mathrm{w} \cdot \mathrm{d} / \mathrm{m}^{2}\right)$ & 1996 & 2796 & 3599 & 4646 & 5559 & 6172 & 6097 & 5613 & 4845 & 3478 & 2405 & 1785 \\
\hline Ho $\quad\left(w \cdot d / m^{2}\right)$ & 4821 & 6163 & 8075 & 9876 & 11118 & 11585 & 11326 & 10324 & 8711 & 6734 & 5140 & 4400 \\
\hline KT & 0.41 & 0.45 & 0.45 & 0.47 & 0.50 & 0.53 & 0.54 & 0.54 & 0.56 & 0.52 & 0.47 & 0.41 \\
\hline
\end{tabular}

Table (3):Mean Monthly meteorological parameters for Kirkuk station during the period (1970-2000)

\begin{tabular}{|c|c|c|c|c|c|c|c|c|c|c|c|c|}
\hline Months & JAN & FEB & MAR & APR & MAY & JUN & JUL & AUG & SEP & OCT & $\mathrm{NOV}$ & DEC \\
\hline $\mathrm{n} / \mathrm{N}$ & 0.62 & 0.67 & 0.68 & 0.70 & 0.76 & 0.86 & 0.87 & 0.91 & 0.92 & 0.84 & 0.76 & 0.65 \\
\hline Mean air temp. $\left(\mathrm{c}^{\circ}\right)$ & 9.2 & 10.8 & 14.3 & 20.2 & 26.8 & 32.3 & 35.5 & 34.9 & 31.2 & 24.9 & 16.9 & 11.0 \\
\hline $\mathrm{RH} \%$ & 70.9 & 65.2 & 59.2 & 50.6 & 33.4 & 22.9 & 21.1 & 22.5 & 24.8 & 35.9 & 55.9 & 70.8 \\
\hline total cloud (octa) & 3.8 & 3.7 & 3.4 & 3.3 & 2.2 & 0.5 & 0.3 & 0.3 & 0.5 & 1.9 & 3.0 & 3.7 \\
\hline Evaporation(mm) & 46.0 & 61.1 & 100.2 & 153.7 & 260.8 & 351.8 & 402.8 & 374.3 & 282.1 & 185.6 & 83.6 & 47.0 \\
\hline Rainfall(mm) & 68.3 & 66.4 & 63.1 & 47.0 & 13.8 & 0.2 & 0.3 & 0.1 & 0.6 & 12.8 & 42.9 & 60.1 \\
\hline $\mathrm{H} \quad\left(\mathrm{w} \cdot \mathrm{d} / \mathrm{m}^{2}\right)$ & 2084 & 2827 & 3738 & 4691 & 5738 & 6578 & 6454 & 6033 & 5159 & 3792 & 2584 & 1895 \\
\hline Нo $\quad\left(\mathrm{w} \cdot \mathrm{d} / \mathrm{m}^{2}\right)$ & 4965 & 6294 & 8175 & 9929 & 11127 & 11570 & 11323 & 10359 & 8793 & 6855 & 5281 & 4547 \\
\hline KT & 0.42 & 0.45 & 0.46 & 0.47 & 0.52 & 0.57 & 0.57 & 0.58 & 0.59 & 0.55 & 0.49 & 0.42 \\
\hline
\end{tabular}


Table (4):Mean Monthly meteorological parameters for Baghdad station during the period (1970-2000)

\begin{tabular}{|c|c|c|c|c|c|c|c|c|c|c|c|c|}
\hline $\begin{array}{l}\text { Months } \\
\text { Meteo. ele. }\end{array}$ & JAN & FEB & MAR & APR & MAY & JUN & JUL & AUG & SEP & OCT & NOV & DEC \\
\hline $\mathrm{n} / \mathrm{N}$ & 0.62 & 0.68 & 0.67 & 0.69 & 0.75 & 0.87 & 0.87 & 0.90 & 0.86 & 0.79 & 0.71 & 0.62 \\
\hline Mean air temp. $\left(c^{o}\right)$ & 9.2 & 11.7 & 15.5 & 22.5 & 28.4 & 32.3 & 34.6 & 33.8 & 30.1 & 23.9 & 16.1 & 10.6 \\
\hline RH\% & 73.5 & 62.2 & 52.7 & 42.5 & 31.8 & 24.8 & 24.3 & 26.8 & 31.5 & 40.9 & 57.3 & 72.2 \\
\hline total cloud (octa) & 3.7 & 3.3 & 3.4 & 3.4 & 2.7 & 0.5 & 0.4 & 0.5 & 0.7 & 2.1 & 3.1 & 3.8 \\
\hline Evaporation(mm) & 69.7 & 102.0 & 177.7 & 266.3 & 383.0 & 500.9 & 558.1 & 505.4 & 369.3 & 238.9 & 123.9 & 70.3 \\
\hline Rainfall(mm) & 49.4 & 35.6 & 34.2 & 23.2 & 8.1 & 0.2 & 0.3 & 0.0 & 0.3 & 7.2 & 26.5 & 36.9 \\
\hline $\mathrm{H} \quad\left(\mathrm{w} . \mathrm{d} / \mathrm{m}^{2}\right)$ & 2864 & 3739 & 4666 & 5617 & 6398 & 7082 & 6977 & 6458 & 5523 & 4311 & 3220 & 2545 \\
\hline Ho (w.d/m $\left.{ }^{2}\right)$ & 4965 & 6294 & 8175 & 9929 & $\begin{array}{c}1112 \\
7\end{array}$ & $\begin{array}{c}1157 \\
0\end{array}$ & $\begin{array}{c}1132 \\
3\end{array}$ & $\begin{array}{c}1035 \\
9\end{array}$ & 8793 & 6855 & 5281 & 4547 \\
\hline KT & 0.54 & 0.56 & 0.55 & 0.56 & 0.57 & 0.61 & 0.62 & 0.62 & 0.61 & 0.6 & 0.57 & 0.52 \\
\hline
\end{tabular}

Table (5):Mean Monthly meteorological parameters for Rutba station during the period (1970-2000)

\begin{tabular}{|c|c|c|c|c|c|c|c|c|c|c|c|c|}
\hline Months & JAN & FEB & MAR & APR & MAY & JUN & JUL & AUG & SEP & OCT & NOV & DEC \\
\hline $\mathrm{n} / \mathrm{N}$ & 0.63 & 0.67 & 0.69 & 0.69 & 0.73 & 0.86 & 0.88 & 0.89 & 0.87 & 0.81 & 0.75 & 0.62 \\
\hline Mean air temp. $\left(\mathrm{c}^{\circ}\right)$ & 7.6 & 9.3 & 13.0 & 18.7 & 23.9 & 28.1 & 30.7 & 30.4 & 27.5 & 21.8 & 14.3 & 9.3 \\
\hline $\mathrm{RH} \%$ & 70.2 & 60.7 & 51.9 & 42.1 & 33.6 & 27.5 & 26.3 & 27.7 & 29.8 & 41.4 & 55.6 & 70.1 \\
\hline total cloud (octa) & 3.2 & 3.1 & 2.8 & 2.4 & 2.0 & 0.4 & 0.3 & 0.4 & 0.8 & 2.1 & 2.8 & 3.3 \\
\hline Evaporation(mm) & 77.5 & 112.5 & 186.5 & 275.2 & 378.1 & 470.0 & 556.1 & 507.5 & 371.1 & 247.3 & 130.2 & 78.5 \\
\hline Rainfall(mm) & 14.3 & 20.5 & 20.2 & 16.1 & 6.7 & 0.1 & 0.1 & 0.0 & 0.4 & 11.3 & 16.3 & 17.8 \\
\hline$H\left(w . d / m^{2}\right)$ & 2565 & 3408 & 4381 & 5661 & 6451 & 7198 & 7159 & 6555 & 5633 & 4345 & 3128 & 2460 \\
\hline Ho (w.d $/ \mathrm{m}^{2}$ ) & 5374 & 6663 & 8450 & 10072 & 11139 & 11520 & 11302 & 10449 & 9017 & 7193 & 5678 & 4963 \\
\hline $\mathrm{KT}$ & 0.48 & 0.51 & 0.53 & 0.56 & 0.58 & 0.62 & 0.63 & 0.63 & 0.62 & 0.6 & 0.55 & 0.5 \\
\hline
\end{tabular}

Table (6):Mean Monthly meteorological parameters for Nasiriya station during the period (1970-2000)

\begin{tabular}{|c|c|c|c|c|c|c|c|c|c|c|c|c|}
\hline $\begin{array}{l}\text { Months } \\
\text { Meteo. ele. }\end{array}$ & JAN & FEB & MAR & APR & MAY & JUN & JUL & AUG & SEP & OCT & NOV & DEC \\
\hline $\mathrm{n} / \mathrm{N}$ & 0.63 & 0.67 & 0.64 & 0.65 & 0.68 & 0.69 & 0.71 & 0.75 & 0.79 & 0.76 & 0.69 & 0.63 \\
\hline Mean air temp. $\left(\mathrm{c}^{\mathbf{o}}\right)$ & 11.7 & 14.0 & 18.5 & 24.9 & 30.7 & 34.2 & 36.0 & 35.7 & 32.9 & 26.9 & 19.3 & 13.3 \\
\hline $\mathrm{RH} \%$ & 68.9 & 59.2 & 50.4 & 41.7 & 31.6 & 23.7 & 22.5 & 23.6 & 27.2 & 37.5 & 53.0 & 66.9 \\
\hline total cloud & 2.8 & 2.3 & 2.3 & 2.4 & 1.7 & 0.5 & 0.3 & 0.3 & 0.3 & 1.5 & 2.2 & 2.7 \\
\hline Evaporation(mm) & 80.1 & 110.7 & 190.1 & 274.9 & 404.8 & 535.4 & 612.1 & 554.2 & 417.8 & 271.9 & 140.7 & 85.3 \\
\hline Rainfall(mm) & 29.2 & 19.2 & 20.9 & 10.5 & 5.0 & 0.2 & $\mathbf{0}$ & $\mathbf{0}$ & 0.8 & 5.6 & 15.0 & 21.2 \\
\hline $\mathrm{H} \quad\left(\mathrm{w} \cdot \mathrm{d} / \mathrm{m}^{2}\right)$ & 2917 & 3825 & 4607 & 5437 & 5952 & 6142 & 6180 & 5913 & 5296 & 4260 & 3226 & 2677 \\
\hline Ho $\left(\mathrm{w} \cdot \mathrm{d} / \mathrm{m}^{2}\right)$ & 5699 & 6951 & 8660 & 10174 & 11138 & 11469 & 11273 & 10508 & 9185 & 7456 & 5993 & 5295 \\
\hline KT & 0.51 & 0.55 & 0.53 & 0.53 & 0.53 & 0.54 & 0.55 & 0.56 & 0.58 & 0.57 & 0.54 & 0.51 \\
\hline
\end{tabular}

\section{Results and Discussion}

Fig (2) show the correlations between the mean monthly values of clearness index and sunshine Ratio $(\mathrm{n} / \mathrm{N})$ in all stations. Linear models is the best fit for all stations . The coefficient of determination $\left(\mathrm{R}^{2}\right)$ exist between $(\mathrm{KT})$ and $(\mathrm{n} / \mathrm{N})$ ranged between $(0.89-0.97)$, this mean that $(89 \%-97 \%)$ of $\mathrm{KT}$ can be accounted using monthly mean $(\mathrm{n} / \mathrm{N})$.

Fig (3) show the correlations between the mean monthly values of KT \& Tmean in all stations. The coefficient of determination $\left(\mathrm{R}^{2}\right)$ is high for all stations except Nasiriya station. This implies that there are statistically significant relationships between KT \& Tmean.

Linear model are the best fit for Mosul ,Kirkuk, and Baghdad stations whereas the quadratic model is the best fit in Rutba and Nasiriya stations . 
Fig (4) show the correlations between the mean monthly values of KT and RH. The correlations is highly acceptable in all stations except Nasiriya station, where $\mathrm{R}^{2}$ are ranged between $(0.78-0.95)$.

Linear model are the best fit for Kirkuk, Baghdad and Rutba stations, whereas quadratic model performed the best fit for Mosul and Nasiriya stations .

Fig (5) show the correlations between the mean monthly values of KT \& cloudiness in all stations. It can be seen that the coefficient of determination $\left(\mathrm{R}^{2}\right)$ implies a good match between the mean monthly values of KT \& cloudiness. The values of $\left(\mathrm{R}^{2}\right)$ ranged between (0.62-0.98). Quadratic model are the best fit in Mosul ,Kirkuk, Rutba and Nasiriya stations whereas power model is the best fit in Baghdad station.

Fig (6) show the correlations between the mean monthly values of clearness index and Evaporation in all stations. The coefficient of determination $\left(\mathrm{R}^{2}\right)$ exist between KT \& Evaporation ranged between (0.75-0.89) for all stations except Nasiriya station which give a weak correlation. Power model is the best fit in Mosul ,Kirkuk , Baghdad and Rutba stations whereas quadratic model is the best fit in Nasiriya station.

Fig (7) show the correlations between the mean monthly values of clearness index and Rainfall in all stations. The correlations is highly acceptable in Mosul, Kirkuk, Baghdad and Rutba stations where the coefficient of determination are ranged between $(0.75-0.94)$. Nasiriya station show a weak correlation. Linear model is the best fit in Mosul ,Kirkuk, Rutba and Nasiriya stations whereas quadratic model is the best fit Baghdad station.

Nasiriya station suffer greatly from duststorm specially during the summer months which attenuate greatly the incoming solar radiation and hence reduce the clearness index during these months. Most of the meteorological parameters and the correlations were affected by this phenomena in Nasiriya station.

Table (7) contain summaries of regression statistics obtained from the different models in all stations. The correlation coefficient $(\mathrm{R})$, coefficient of determination $\left(\mathrm{R}^{2}\right)$,Mean absolute Error (MAE) and Root Mean Square Error (RMSE) varies from one station to another, and also vary from one variable to another .

MAE is found in a range of $(0.94-9.8) \%$ indicating a fairly good fitting between KT and considered meteorological parameters.

It is quite obvious from the table (7) that RMSE is lies between $(1.17,7.86) \%$ in all stations which also shows a good performance of all the models examined .
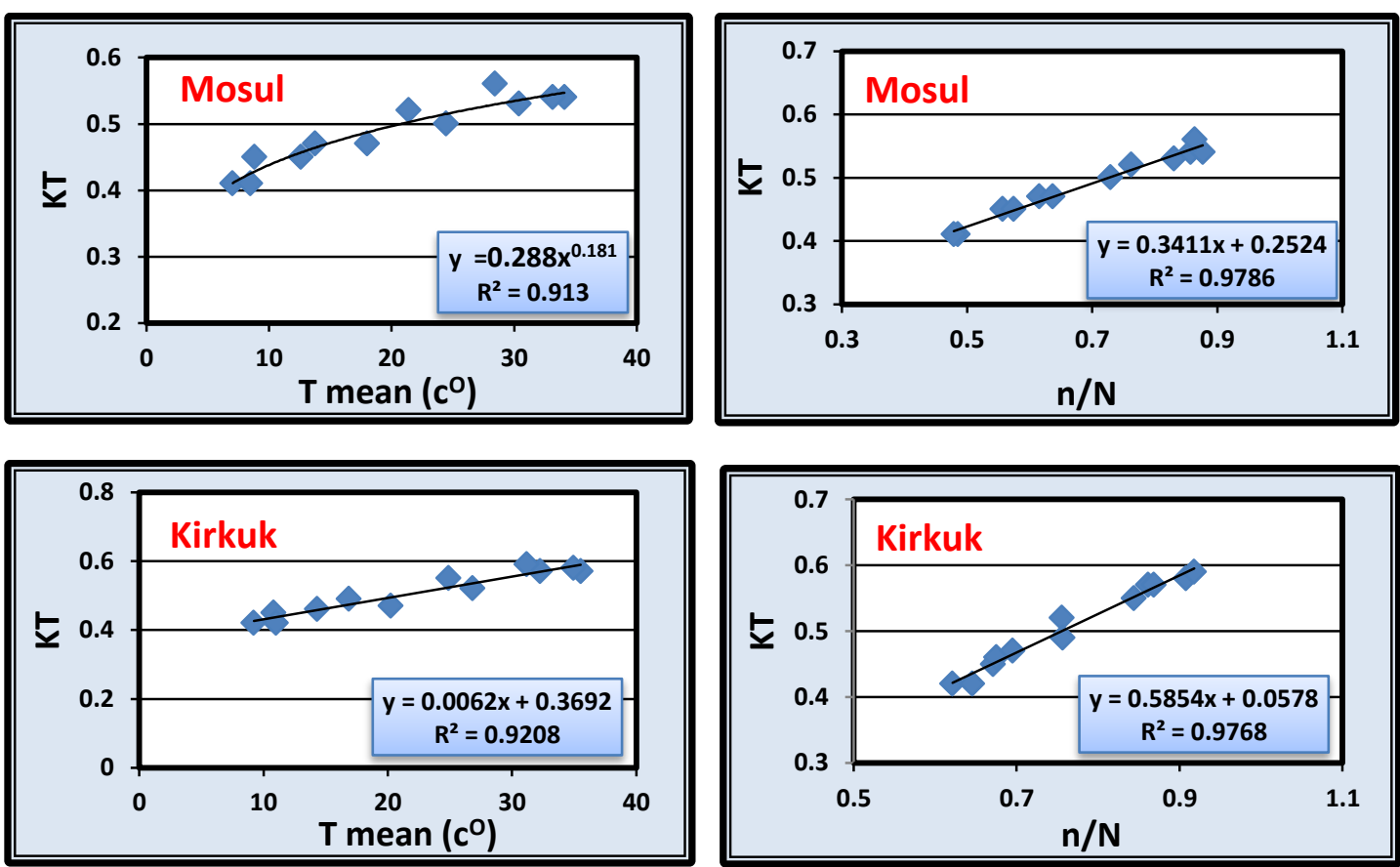

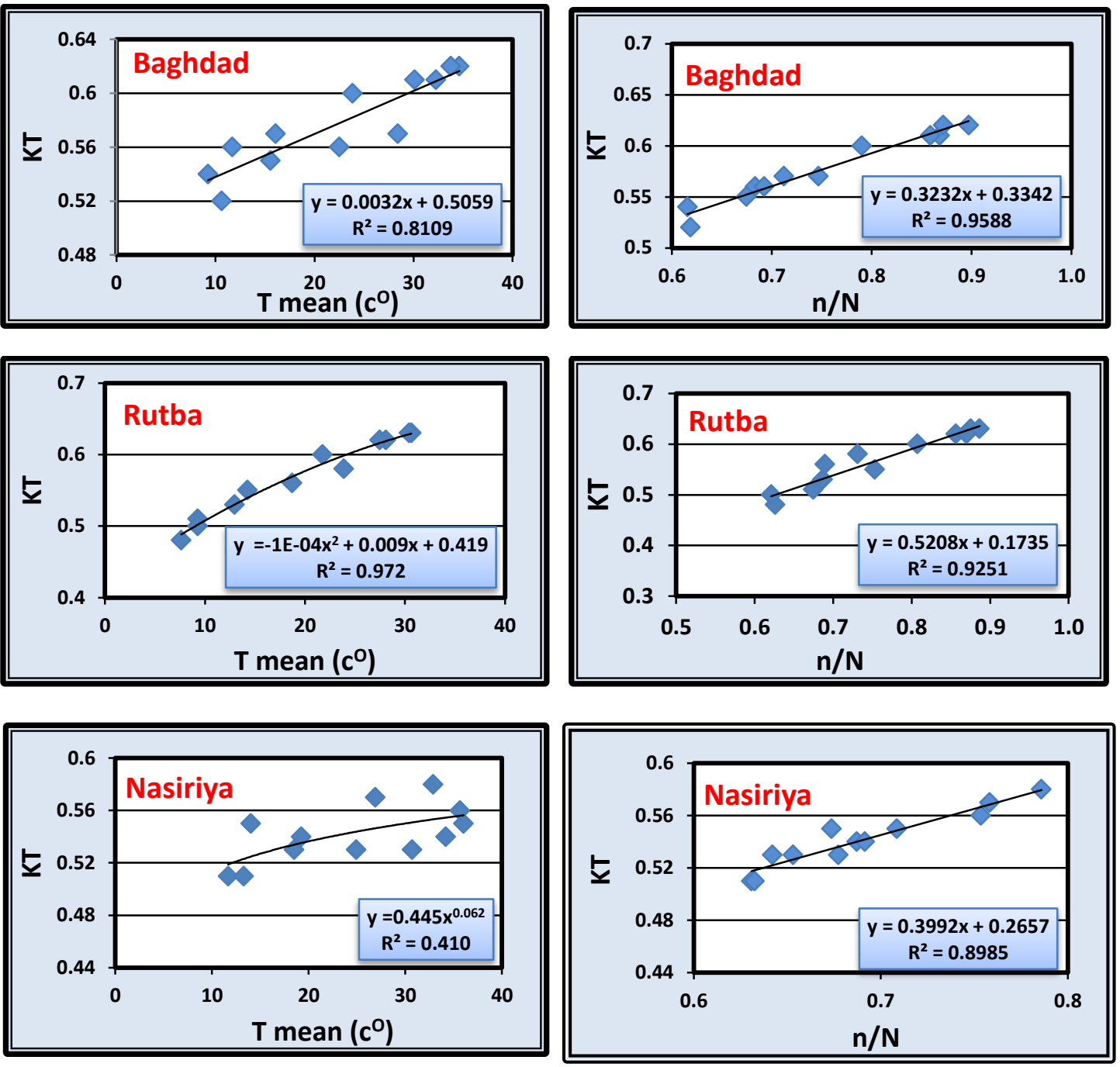

Fig(3): correlations between KT \& Tmean for all stations

Fig(2): correlations between KT \& n/N
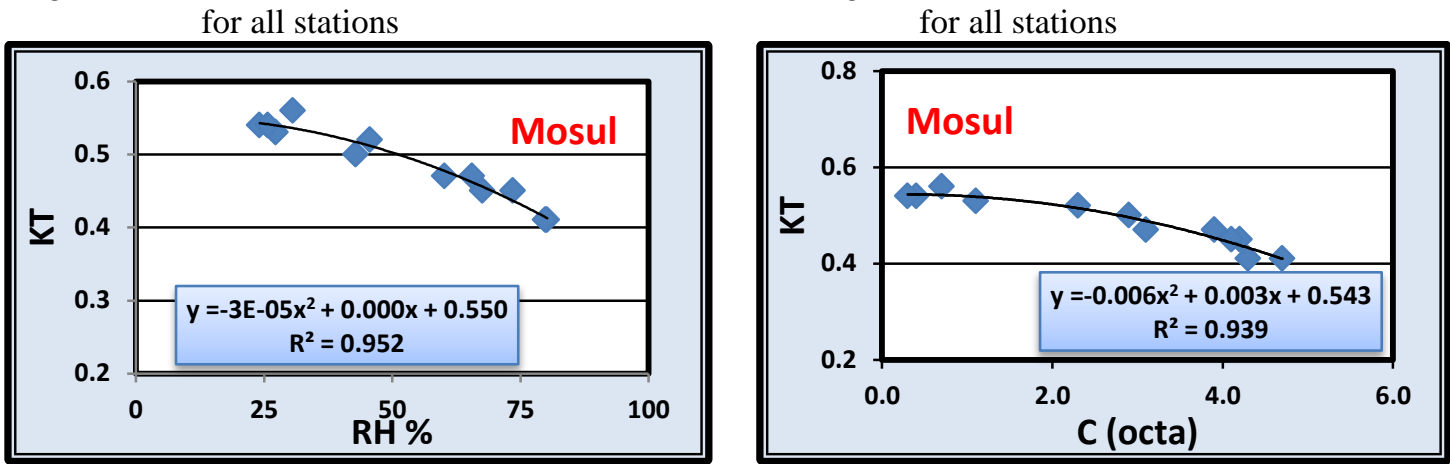

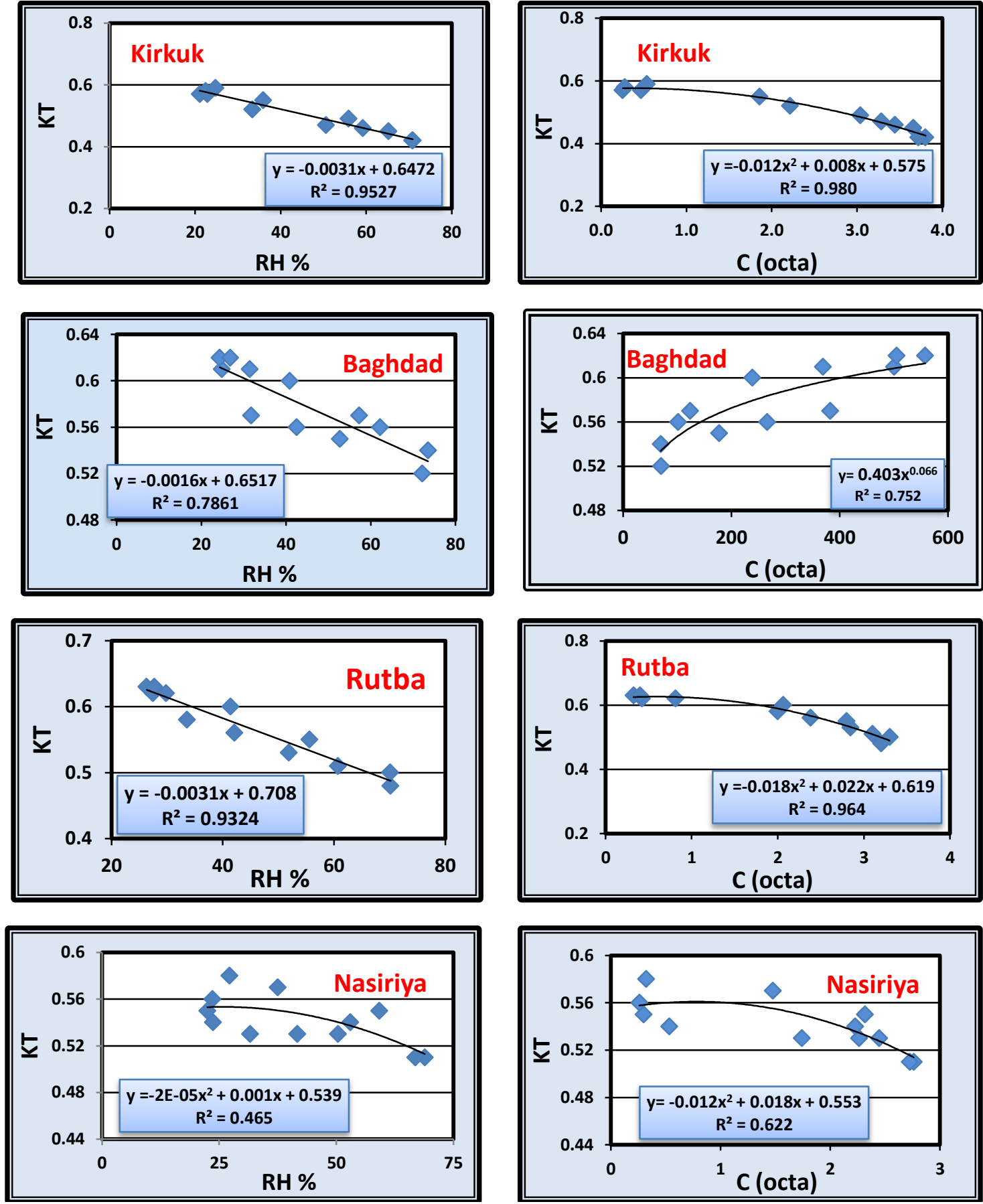

Fig(5): correlations between KT \& RH for all stations

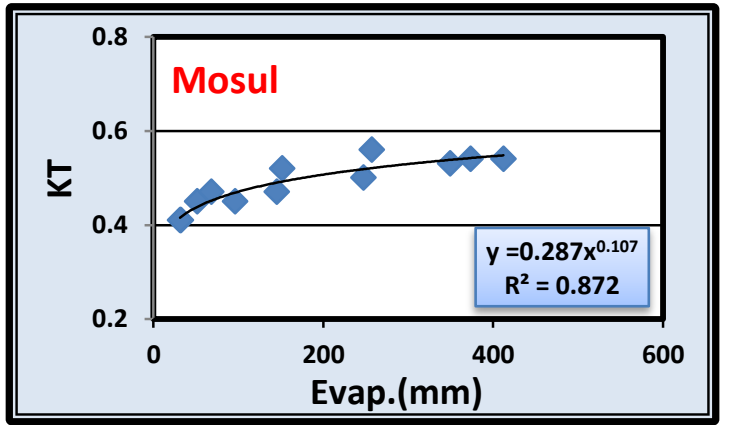

Fig(4): correlations between KT \& C

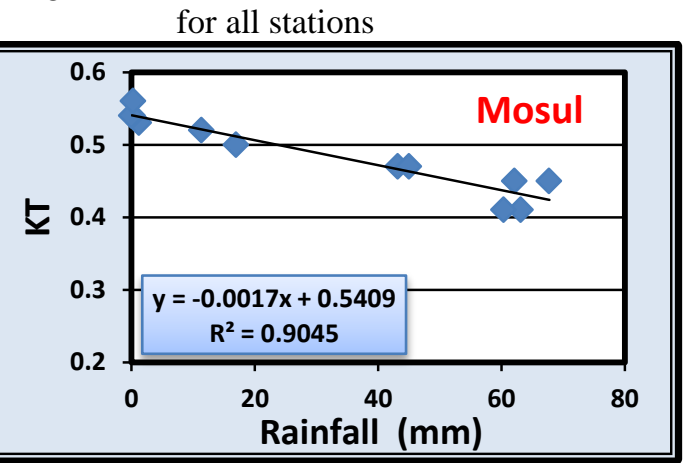


Estimation of clearness index from different meteorological parameters in IRAQ
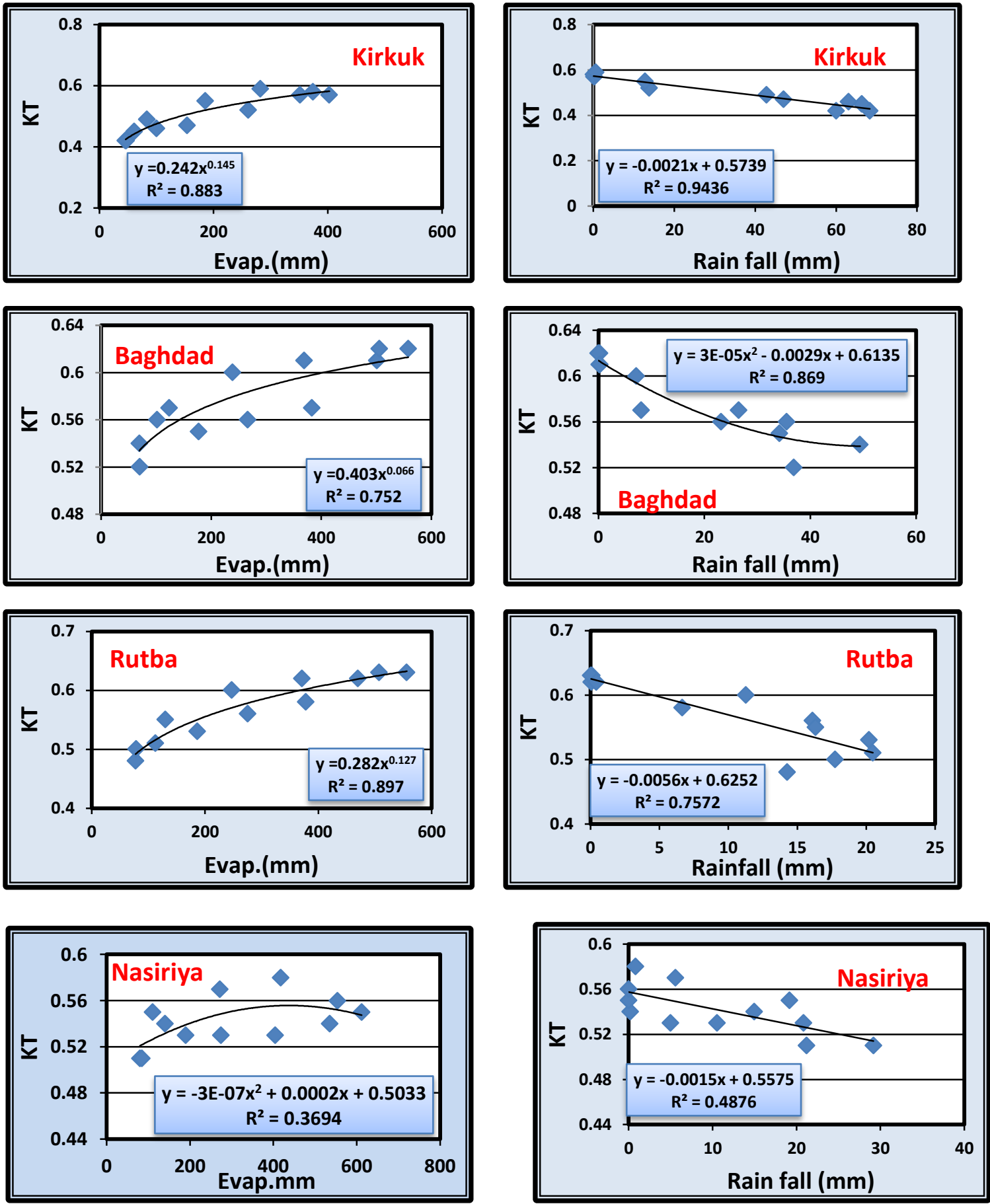

Fig(7): correlations between KT \& Evap. for all stations

Fig (6):correlations between KT \& Rainfall for all stations 
Estimation of clearness index from different meteorological parameters in IRAQ

able (7) : Models with Regression and statistical Indicators for all Stations

\begin{tabular}{|c|c|c|c|c|c|}
\hline Stations & correlations & $\overline{\mathbf{R}}$ & $\overline{\mathbf{R 2}}$ & MAE & $\overline{\text { RMSE }}$ \\
\hline Mosul & KT $=0.3411(n / N)+0.2524$ & 0.989 & 0.978 & 1.26 & 1.45 \\
\hline Kirkuk & $\mathrm{KT}=\mathbf{0 . 5 8 5 4}(\mathrm{n} / \mathrm{N})+\mathbf{0 . 0 5 7 8}$ & 0.988 & 0.976 & 1.47 & 1.89 \\
\hline Baghdad & $\overline{K T}=0.3232(\mathrm{n} / \mathrm{N})+0.3342$ & 0.979 & 0.958 & 0.97 & 1.17 \\
\hline Rutba & $K T=0.5208(n / N)+0.1735$ & 0.962 & 0.925 & 1.92 & 2.58 \\
\hline Nasiriya & $\mathrm{KT}=0.3992(\mathrm{n} / \mathrm{N})+0.2657$ & 0.948 & 0.898 & 0.94 & 1.23 \\
\hline Stations & correlations & $\mathbf{R}$ & $\mathbf{R 2}$ & MAE & RMSE \\
\hline Mosul & KT $=0.2886$ Tmean 0.1812 & 0.956 & 0.913 & 2.51 & $\overline{3}$ \\
\hline Kirkuk & $\mathrm{KT}=0.0062 \mathrm{Tmean}+0.3692$ & 0.960 & 0.920 & 2.89 & 3.34 \\
\hline Baghdad & KT = 0.0032 Tmean + 0.5059 & 0.90 & 0.810 & 6.79 & 7.48 \\
\hline Rutba & 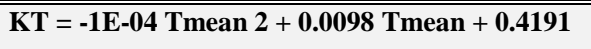 & 0.986 & 0.972 & 4.01 & 4.85 \\
\hline Nasiriya & KT $=0.4456$ Tmean 0.062 & 0.641 & 0.410 & 9.84 & 4.41 \\
\hline Stations & correlations & $\overline{\bar{R}}$ & $\mathbf{R 2}$ & $\overline{\text { MAE }}$ & $\overline{\text { RMSE }}$ \\
\hline Mosul & KT $=-0.0067 \mathrm{c} 2+0.0031 \mathrm{c}+0.5439$ & 0.969 & 0.939 & 2.08 & 2.63 \\
\hline Kirkuk & KT = -0.0126 c $2+0.0084 \mathrm{c}+0.5756$ & 0.99 & 0.980 & 1.48 & $\overline{1.71}$ \\
\hline Baghdad & KT = 0.4031c0.0663 & 0.867 & 0.752 & 2.49 & 2.80 \\
\hline Rutba & KT = -0.0187 c $2+0.0221 \mathrm{c}+0.6199$ & 0.982 & 0.964 & 1.48 & 1.82 \\
\hline Nasiriya & KT = -0.012 c $2+0.0188 \mathrm{c}+0.5536$ & 0.789 & 0.623 & 1.89 & 2.31 \\
\hline $\begin{array}{l}\text { Stations } \\
\end{array}$ & correlations & $\overline{\overline{\mathbf{R}}}$ & $\mathbf{R 2}$ & 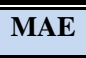 & 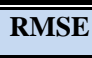 \\
\hline Mosul & KT = -3E-05RH2 + 0.0003RH+ 0.5505 & 0.976 & 0.952 & 3.83 & 4.71 \\
\hline Kirkuk & KT = -0.0031RH + 0.6472 & 0.976 & 0.952 & 2.26 & 2.61 \\
\hline Baghdad & KT = -0.0016 RH + 0.6517 & 0.887 & 0.786 & 2.26 & 2.66 \\
\hline Rutba & KT = -0.0031 RH + 0.708 & 0.966 & 0.932 & 2.12 & 2.41 \\
\hline Nasiriya & KT = -2E-05 RH 2 + 0.0011x + 0.539 & 0.682 & 0.466 & 2.53 & 2.85 \\
\hline Stations & correlations & $\overline{\mathbf{R}}$ & $\mathbf{R 2}$ & MAE & RMSE \\
\hline Mosul & KT = -0.0017Rainfall+ 0.5409 & 0.951 & 0.905 & 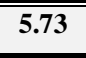 & $\overline{7.86}$ \\
\hline Kirkuk & KT = -0.0021x Rainfall + 0.5739 & 0.971 & 0.944 & 2.45 & 3.08 \\
\hline Baghdad & KT = 3E-05 Rainfall 2 - 0.0029 Rainfall + 0.6135 & 0.932 & 0.869 & 1.55 & 2.15 \\
\hline Rutba & KT $=-\mathbf{0 . 0 0 5 6}$ Rainfall + 0.6252 & 0.87 & 0.757 & 3.35 & 4.96 \\
\hline Nasiriya & KT = -0.0015 Rainfall + 0.5575 & 0.698 & 0.487 & 2.33 & 2.70 \\
\hline Stations & correlations & $\overline{\mathbf{R}}$ & $\mathbf{R 2}$ & 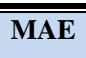 & $\overline{\overline{\text { RMSE }}}$ \\
\hline Mosul & KT = 0.2874Evap.0.1073 & 0.934 & 0.872 & 3.15 & 3.63 \\
\hline Kirkuk & KT = 0.2428 Evap.0.1458 & 0.94 & 0.883 & 3.36 & 4.14 \\
\hline Baghdad & KT = 0.4031 Evap.0.0663 & 0.867 & 0.752 & 2.49 & 2.80 \\
\hline Rutba & KT = 0.2827 Evap.0.1274 & 0.947 & 0.897 & 2.48 & 2.94 \\
\hline Nasiriya & KT = -3E-07 Evap.2 + 0.0002 Evap. + 0.5033 & 0.608 & 0.369 & 3.60 & 4.44 \\
\hline
\end{tabular}




\section{Conclusion}

The clearness index for five meteorological stations in Iraq has been expressed of (sunshine ratio, relative humidity, cloudiness, mean air temperature, rain fall, evaporation ) applying a variety of regression models. The significance and performance characteristic of the models have been viewed using several statistical tests (R, $R^{2}$, MAE,MBE).

The result showed that linear model gave the best fit for the relation between $(K T \& n / N),(K T \&$ Rainfall) in all stations .

Quadratic model and power model gave the best fit for the relation between (KT \& c), (KT \& Evap.) respectively, while linear, power and quadratic models gave the best fit between (KT \& Tmean), (KT \& RH).

\section{References}

[1]. Mellit, A., eadj Arab, A .,shaar ,S .,(2007), "An Anfis - Based prediction for monthly clearness index and daily solar radiation : Application for sizing of a stand- alone Photovoltaic system ", Journal of physical science, vol. 18(2), pp.15-35.

[2]. Serban, C. ,(2009)," Estimating Clear Sky Solar Global Radiation Using Clearness Index, for Brasov Urban Area" Proceedings of the 3rd International Conference on Maritime and Naval Science and Engineering.

[3]. Waewsak, J. and chancham, C.,(2010),"The clearness index model for estimation of global solar radiation in Thailand", thammasat Int., J.Sc.Tech.,vol.15,No.2.

[4]. Augustine, C. and Nnabuchi, M.N.,(2009),"Correlation of Cloudiness Index with Clearness Index for Four Selected Cities in Nigeria.", The Pacific Journal of Science and Technology,vol.10,NO.2.

[5]. Iqbal, M.,(1983),"An introduction to solar radiation", Academic Press, Canada.

[6]. Nematollahi, O., Alamdari P. and Alemrajabi A. A.,(2011), "Monthly mean clearness index for Few Iranian Cities" , 10th International conference on sustainable Energy Technologies, İstanbul, Turkey.

[7]. Hacer, D. \& HarunA.,(2012),"Sunshine-based estimation of global solar radiation on horizontal surface at Lake Van region"ELsevier,vol.58,pp.35-46.

[8]. Falayi, E.O., Adepitan, J.O., Rabiu, A.B.,(2008),"Empirical models for the correlation of global solar radiation with meteorological data for Iseyin, Nigeria. ",The Pacific journal of science and Technology,vol.9,No.2.

[9]. Trabea, A.A., Shaltout, M.A.,(2000)," Correlation of global solar radiation with meteorological parameters over Egypt", Renewable Energy,vol.21,pp.297-308.

[10]. Rahman, S.,(1998),"solar radiation over saudia arabia and comparisons with empirical models",Energy,23(12),pp.1077-1082.

[11]. Wu, G., Liu, Y., Wang, T.,(2007),"Methods and strategy for modeling daily global solar radiation with measured meteorological data - a case study in Nanchang station", China. Energy Converse Manage, vol. 48,pp. 2447-2452. 